\title{
COMPETITIVENESS AND DEVELOPMENT OF LOCAL COMMUNITIES IN THE REPUBLIC OF SRPSKA
}

\author{
Mladen Rebić, Milica Bojat, Nemanja Šarenac \\ University of East Sarajevo, Faculty of Economics Pale, Bosnia and Herzegovina
}

date of paper receipt:

03.05.2018. date of sending to review:

05.05.2018. date of review receipt:

16.05.2018.

Review article

doi: 10.2478/eoik-2018-0010

UDK: 330.34:005

\section{SUMMARY}

There is no universal model of local economic development. Development strategies vary from country to country, city to city, and depend on the level of development, political system, development potential, social values, available resources, etc. Republic of Srpska faces with significant differences in the level of development of its territory. Local communities in the Republic of Srpska are increasingly facing with several obligations - providing support to business, creating a favorable business environment for attracting investment and providing an adequate infrastructure. The biggest problems that most of municipalities in the Republic of Srpska encounter are reflected in the emptying of cities, the departure of young people, low average wages and high unemployment rates. They are trying to solve these problems by attracting investments. However, it is very important to say that an effective investment policy must be based on the creation of new enterprises with capitalintensive production. The average wage level in local communities of the Republic of Srpska is low, due to the fact that most of the investments have a labor-intensive character. The subject and aim of this paper is to determine the competitiveness and level of development of local communities in the Republic of Srpska. Municipal competitiveness will be higher if it has a positive trade balance, higher average wages, high natural increase, low unemployment rate and positive migration. Higher natural increase, favorable trade balance and low unemployment rate are in direct correlation with the degree of local development. The results of the research have shown that the key problems of underdeveloped municipalities in the Republic of Srpska are demographic aging, population migration, underdeveloped infrastructure, high unemployment rates, low average wages, low level of investment, low export activity, weak institutional capacities, etc.

Keywords: unemployment, investment, migration, competitiveness, development strategy

\section{INTRODUCTION}

The concept of local community means a set of institutions by which citizens directly or indirectly, through elected representatives, manage certain public affairs, in their own interests and in accordance with the existing legal system. Local community represents the highest level of the local government autonomy in relation to the central government in performing local affairs. It includes the citizens $\$$ right to elect representatives in local assemblies, mayors, as well as the freedom to appoint elected officials and other local authorities. (Begović et al. 2006). 
Variable economic and social conditions cause the creation of inequalities in the development of certain areas - regions and localities. Insufficiently developed areas usually give a small contribution to the country's economic development and its international competitiveness. That is why each country must implement an adequate regional politics that will harmonize and improve the living conditions of the whole territory.

The overall socio-economic development of the SFRY in the period after the Second World War included the economic growth, growth of the living standard, the prolonged life span, the reduction in mortality, the increase in the number of educated population, the increase in employment, etc. During that period, there was a current issue of regional development, throughout the whole country, so the development plans mainly were referring to the development of undeveloped areas and more balanced territorial development. Bosnia and Herzegovina, Macedonia, Montenegro, Kosovo and Metohija were considered as economically underdeveloped republics. There was almost no industry in this area. Mostly, there were small companies dealing with processing of wood or agricultural products. Hydropower potentials and minerals were not used, traffic was not developed, unemployment was on high level, etc. The state tried to carry out certain activities in order to reduce the differences in the level of development of its territory. So, it established the Fund for the underdeveloped and the Fund for financing the increasing employment, which were collecting domestic and foreign capital and directed it to project financing. Although the situation of the undeveloped areas, in relation to the developed ones, was significantly improved after the break-up of the SFRY, certain inequalities in material and social development between the republics, as well as within them, have been inherited.

Today, the situation in Bosnia and Herzegovina is such that there is a big gap between developed and undeveloped local communities. Small, undeveloped municipalities are mostly closed, poor and dependent on transfers from higher levels of government - entities and cantons.

A theritory of Republic of Srpska has 63 local communities - 56 municipalities and 7 cities. Local communities have different socio-economic parameters - the number of inhabitants and their basic characteristics, the area and characteristics of the territory, the availability of natural resources, the degree of development, the availability of infrastructure, etc. It has 33 undeveloped municipalities. Nineteen of them are significantly underdeveloped. There are great differences between rural and urban areas.

The paper will start with an overview of the current research of local community and the way it is defined by different authors. Then, it will be made a SWOT analysis of the current state of local communities in the Republic of Srpska, in order to find out on which forces and chances should be based its further development, as well as the weaknesses that need to be minimized and the threats that need to be avoided. After that, a detailed analysis of the development of local communities will show how many local communities are different in several basic parameters - population, birth rate, mortality rate, migration rate, natural increase, number of employees, number of persons seeking employment, average net salary, level of import and export.

\section{LITERATURE REVIEW}

Access to the study of local community implies multidisciplinarity, because it is necessary to well know politics, economics, sociology, history, etc. to be able to study of the system of local community. As a discipline, the local community deals with the knowledge that includes all three levels of generality, because it is partly a fundamental scientific discipline, and at the same time develops the knowledge of the middle level of the generality - comparative systems on which most principles and norms are reviewed and verified. Also, empirical analysis represents a very important level, without which the local community could not be studied and understood (Batley and Stoker, 1991; Bennet, 1990; Sellers, 2002). 
King (1992) and Walzer (1995) consider that primary issues that local community deal with, refers to development and meeting the general needs of the community through a system of local public services. In their opinion, this is primarily about communal affairs, spatial planning, construction, education, health care, culture, ecology, security and, of course, encouraging local economic development and strengthening entrepreneurial management.

Peters (1998) consider that method of comparison is the most important for local government research. He thinks that the advantages of this method are in the great cognitive potential arising from the comparison of institutions, institutes, relationships and processes in different countries. It is used to perform some general theoretical knowledge. In these processes method of synthesis, deduction and generalization are used.

Economic factors have largely shaped cities through the choice of location of a settlement, the way and dynamics of development, infrastructure and appearance (Sullivan, 1990). According to David Osborne (1992), the city and market are categories of a similar set of values and sizes. Osborn thinks that cities are like markets, because they represent wide and complex aggregations of people and institutions in which everyone constantly makes decisions and influences the behavior of others through information and incentives. Also, contemporary local government has the participation of citizens and their constant initiative, control and participation, exatly as one of its most important qualities (Geissel, 2009).

By analyzing different definitions of the local community, Pusić (1963) came up with five elements that constitute an assumption for the constitution and functioning of the local community: space, people, needs, common activities, with the aim of meeting common needs and interests. An mutually interaction creates a value-based upgrade that gives cohesion and stability to the local community. Pusic interprets local community as a process, and observes its elements through their unity and interaction, which allows the systematization of basic assumptions for the constitution of local communities.

Bartik (2003) observes local community as an important segment of the state. He believes that citizens expect the republic authorities to achieve two basic goals - reducing unemployment and raising living standards - but they expect the same thing from the local authorities, too.

Reiss (1959) views the local community through the prism of people's interrelations and thinks that it is created because people live and take care of themselves in a limited space. Besides, community works to meet common needs through various forms of social action. Bander (1959) defines the local community as a set of subsystems such as family, schools, churches and businesses in a particular territory. Šuvar (1973) thinks that when a legal-political and systemic institution is formed in one or more connected settlements, then it acquires the status of a local community and constitutes itself in the form of a municipality as a basic local community.

\section{SWOT ANALYSIS OF THE REPUBLIC OF SRPSKA}

The SWOT analysis shows the current state of the local communities in the Republic of Srpska. It provides an overview of the most important factors that influence local development. Factors are divided into strengths and weaknesses, as internal factors, and chances and threats as environmental factors that can not be influenced.

The development of local communities should be based on established forces from the SWOT analysis, i.e. on the development strategies of municipalities, on resources and natural resources, as well as on the good cooperation of all levels of government in the Republic of Srpska. Strengthening municipal competitiveness and development can also be achieved through the withdrawal of funds from IPA funds, creating a good business environment by obtaining appropriate certificates (BFC certificate - Business Friendly Certificate), as well as more actively involving public-private partnerships in the implementation of strategic and operational goals. 
On the other hand, the main weaknesses and threats are manifested through the lack of capable and trained personnel for the preparation and implementation of development projects and major differences in the level of development of municipalities. The biggest problem that almost all municipalities in the RS are faced with is the departure of young people and the population in general abroad and in bigger cities in Bosnia and Herzegovina and in the surrounding. Also, the acute problem of municipalities and the biggest brake on the implementation of development projects is the chronic lack of financial resources.

Table 1 SWOT analysis of the development of municipalities in RS

\begin{tabular}{|c|c|}
\hline STRENGHTS & WEAKNESSES \\
\hline $\begin{array}{l}\text { most municipalities adopted development } \\
\text { strategies and programs }\end{array}$ & $\begin{array}{l}\text { excessive orientation to seek help from higher levels } \\
\text { of government }\end{array}$ \\
\hline $\begin{array}{l}\text { commitment to the implementation of the } \\
\text { decentralization process }\end{array}$ & $\begin{array}{l}\text { lack of experts to prepare and implement } \\
\text { development projects }\end{array}$ \\
\hline $\begin{array}{l}\text { the wealth of natural resources for potential } \\
\text { investors }\end{array}$ & $\begin{array}{l}\text { marked differences in size, level of development } \\
\text { and capacity of local governments }\end{array}$ \\
\hline $\begin{array}{l}\text { good cooperation between the key actors - the } \\
\text { National Assembly, the Government, the Ministry } \\
\text { of Administration and Local Government, } \\
\text { municipalities }\end{array}$ & $\begin{array}{l}\text { inconsistency of development priorities of local } \\
\text { governments with the priorities in the development } \\
\text { strategy of RS }\end{array}$ \\
\hline $\begin{array}{l}\text { willingness of local governments to improve their } \\
\text { competitiveness }\end{array}$ & oversized and inefficient municipal administration \\
\hline OPPORTUNITIES & THREATS \\
\hline $\begin{array}{l}\text { active participation of local government in the } \\
\text { process of EU integration }\end{array}$ & demographic depopulation of rural areas \\
\hline $\begin{array}{l}\text { project approach with funds from pre-accession } \\
\text { IPA funds and the RS Development Fund }\end{array}$ & $\begin{array}{l}\text { lack of financial resources required for } \\
\text { implementation of the delegated competence }\end{array}$ \\
\hline creating a stimulating local business environment & $\begin{array}{l}\text { lack of awareness of the population on projects of } \\
\text { interest for local government }\end{array}$ \\
\hline $\begin{array}{l}\text { public-private partnership as a model for better } \\
\text { utilization of resources and higher income of local } \\
\text { government }\end{array}$ & $\begin{array}{l}\text { inherited unresolved property-legal relations } \\
\text { that limit economic development and resource } \\
\text { management }\end{array}$ \\
\hline $\begin{array}{l}\text { strengthening mutual cooperation of local } \\
\text { governments on joint projects }\end{array}$ & $\begin{array}{l}\text { insufficient readiness to reconcile the interests of the } \\
\text { republic and local authorities, local authorities and } \\
\text { local communities, citizens and local authorities }\end{array}$ \\
\hline $\begin{array}{l}\text { strengthening of good relations between local } \\
\text { and republic institutions in the field of strategic } \\
\text { planning }\end{array}$ & \\
\hline
\end{tabular}

Source: Author's calculation

A conclusion that can be drawn from this analysis is that the local government should provide a stable system of financing, effective enforcement of responsibilities, transparency, citizen participation in decision-making and quality management of scarce resources. The implementation of these activities, at the level of local governments, greatly contributes to the balanced development of the RS. 


\section{ANALYSIS OF LOCAL COMMUNITIES DEVELOPMENT OF THE REPUBLIC OF SRPSKA}

On Picture no. 1 it can be seen that, according to data from 2017, there are 18 developed, 12 middledeveloped, 14 underdeveloped and 19 extremely underdeveloped units of local governments in RS. The most developed is considered the City of Banja Luka.

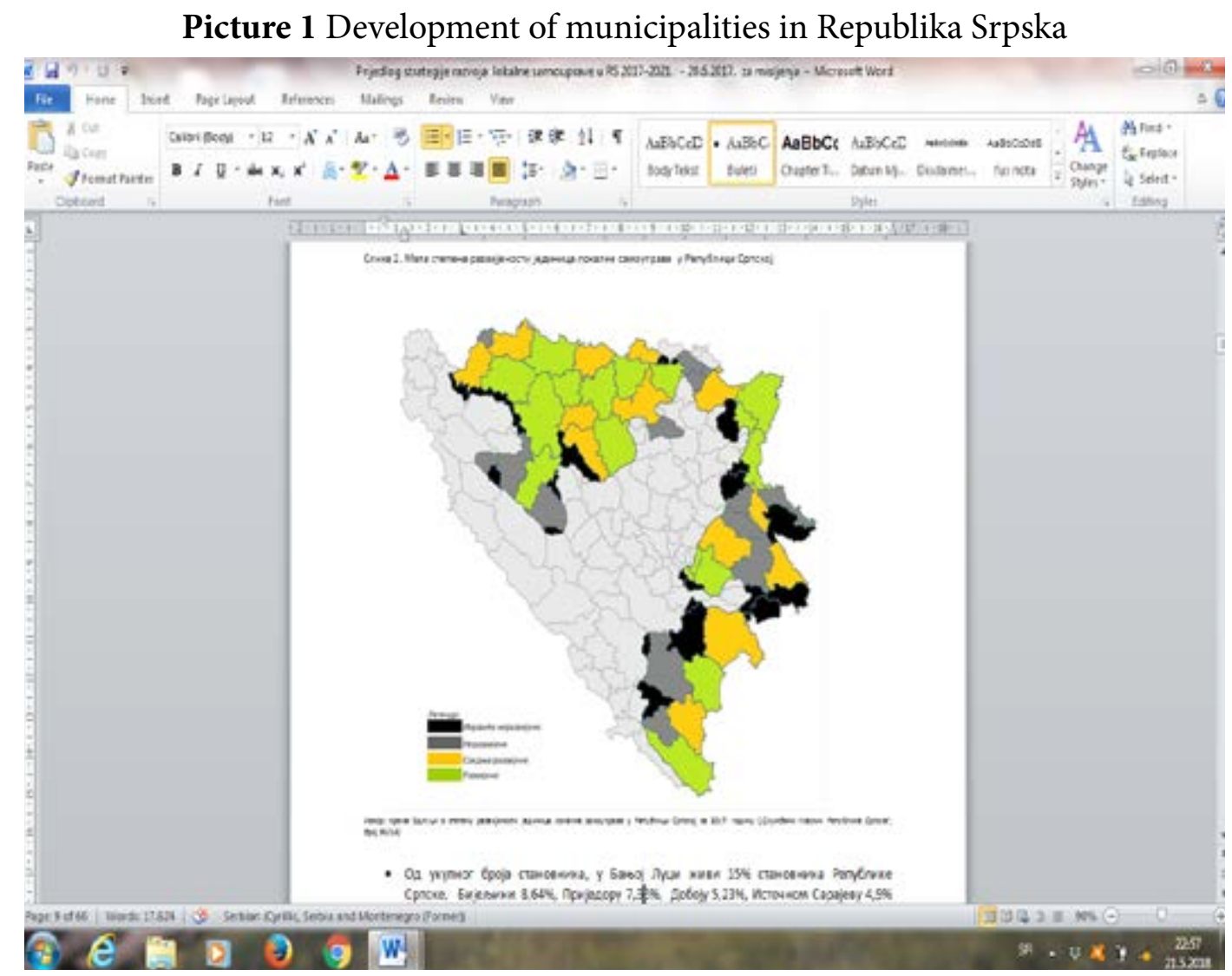

Source: Prijedlog strategije razvoja lokalne samouprave u RS 2017-2021, 2017.

Demographic changes are very important for planning local economic development, because the population is a very important sector that participates in the process of production and also in the process of consumption of products and services. Reducing the number of inhabitants will also reduce economic activity in a given territory

Of the total population of the Republic of Srpska in Banja Luka lives 15\%, 8.64\% in Bijeljina, Prijedor, 7.35\%, Doboj 5.23\%, East Sarajevo $4.9 \%$, while only $0.01 \%$ of the population lives in Drvar and $0.02 \%$ in Eastern Mostar. From Table no. 2 it is evident that the number of inhabitants is highest in the developed, and the lowest in heavily underdeveloped municipalities. $68.9 \%$ of the population is populated in developed municipalities, while only 6.85\% live in 19 extremely underdeveloped municipalities. The average number of inhabitants in the developed municipality is 44,798 , and in the significantly underdeveloped it is 10 times less, ie 4,219 inhabitants. These data are sufficient evidence of uneven distribution of population by municipalities and cities. Underdeveloped areas characterized by low population density, continuous decrease of population and migration to more urban areas. 
Table 2 Overview of the population of RS by municipalities

\begin{tabular}{|l|r|r|r|}
\hline $\begin{array}{c}\text { Type of local } \\
\text { municipalities according } \\
\text { to development }\end{array}$ & $\begin{array}{c}\text { Number of } \\
\text { inhabitants }\end{array}$ & \multicolumn{1}{|c|}{$\begin{array}{c}\text { Number of } \\
\text { municipalities }\end{array}$} & \multicolumn{2}{|c|}{$\begin{array}{c}\text { Average number } \\
\text { of inhabitants in } \\
\text { municipalities }\end{array}$} \\
\hline Developed & 806.365 & 18 & 44.798 \\
\hline Middle-developed & 172.422 & 12 & 14.369 \\
\hline Underdeveloped & 111.387 & 14 & 4.956 \\
\hline Heavily underdeveloped & 80.168 & 19 & 4.219 \\
\hline Total & 1.170 .342 & 63 & 18.577 \\
\hline
\end{tabular}

Source: Author's calculation according to the 2013 census

The average population density of RS is 53.85 inhabitants per square kilometer. The largest density of settlements we have in East Ilidza, East New Sarajevo, Zvornik and Banja Luka, and the smallest is in Eastern Drvar, Petrovac, Istočni Mostar and Kalinovik. Positive migration balances are recorded in Banja Luka, Bijeljina, Trebinje, Istočno Sarajevo, Laktaši, while most other municipalities record a negative migration balance. The reason for the frequent migration of rural population to urban areas lies in the larger labor market and the process of industrialization.

One of the demographic characteristics of the Republic of Serbian is a negative birth rate in all municipalities, with the exception of Banja Luka. The general rate of natural growth in 2015 was negative and was $-4 \%$. When looking at the population, the biggest decline is recorded in developed and mid-sized municipalities, as they have the highest population. Regarding to the rate of natural growth, the largest percentage of population decline is characterized by underdeveloped and highly underdeveloped municipalities. The reason for negative natural growth is a very low birth rate (less than 10\%) and a generally stable mortality rate of $9-11 \%$. The highest rate of birth is East New Sarajevo (11.24\%), Trebinje (9.44\%) and Banja Luka (9.07\%), and the lowest Pelagic (0.35\%), Donji Žabar (0.76\%) and Kalinovik (0.93\%). Krupa na Uni $(22.12 \%)$ and Petrovac (18.26\%) and the lowest Cajnice (7.68\%), New Gorazde (7.36\%) and Vukosavlje (7.27\%) recorded the highest rate of mortality.

Migration balance for the entire RS in 2015 amounted to 168 people. The reason for this is that most young people leave in search of employment and better living conditions. The largest population inflow was in middle-developed municipalities.

Table 3 Demographic trends of the RS population per municipalities in 2015

\begin{tabular}{|l|r|r|r|r|r|r|r|}
\hline $\begin{array}{c}\text { Type of local } \\
\text { municipalities } \\
\text { according to } \\
\text { development }\end{array}$ & \multicolumn{2}{|c|}{ Natality } & \multicolumn{2}{c|}{ Mortality } & \multicolumn{2}{c|}{ Natural growth } & \multirow{2}{*}{$\begin{array}{c}\text { Migration } \\
\text { balance }\end{array}$} \\
\cline { 2 - 8 } & Number & $\begin{array}{c}\text { Average } \\
\text { rate }\end{array}$ & Number & $\begin{array}{c}\text { Average } \\
\text { rate }\end{array}$ & Number & $\begin{array}{c}\text { Average } \\
\text { rate }\end{array}$ & -900 \\
\hline Developed & 7.069 & $7,34 \%$ & 10.190 & $9,22 \%$ & -3.121 & $-3,86 \%$ & -133 \\
\hline $\begin{array}{l}\text { Middle- } \\
\text { developed }\end{array}$ & 1.313 & $6,10 \%$ & 2.447 & $11,06 \%$ & -1.134 & $-4,95 \%$ & -314 \\
\hline Underdeveloped & 597 & $4,22 \%$ & 1.475 & $11,30 \%$ & -878 & $-7,07 \%$ & -751 \\
\hline $\begin{array}{l}\text { Heavily } \\
\text { underdeveloped }\end{array}$ & 378 & $3,36 \%$ & 947 & $10,15 \%$ & -587 & $-6,79 \%$ & 168 \\
\hline Total & 9.357 & $6,60 \%$ & 15.059 & $10,6 \%$ & -5.720 & $-4,00 \%$ & \\
\hline
\end{tabular}

Source: Author's calculation acording to Prijedlog strategije razvoja lokalne samouprave u

RS 2017-2021, 2017.

Most municipalities are characterized by a high and rising unemployment rate, with a large share of long-term unemployment and youth unemployment. According to data from 2016, 26.18\% of the total number of employed persons were in Banja Luka, 8.21\% in Bijeljina, 5.93\% in Eastern Sarajevo, $5.37 \%$ in Prijedor. Also, the largest number of people looking for employment is located in these 
cities. (Prijedlog strategije razvoja lokalne samouprave u RS 2017-2021, 2017). The largest number of employees (approximately 90\%) is located in developed and medium developed municipalities, which is natural, since they are mainly concerned larger cities, with a larger volume of economic activities. About $80 \%$ of those who are actively seeking employment are also located in this area. In all four observed categories, the number of employed increased in 2016 compared to 2015.

In the Republic of Srpska there are large differences in the average salary per municipality. Thus, the average net salary in RS in 2016 was KM 836. At the same time, the highest average wage was in Stanari municipality (BAM 1.142), and the lowest in Kupres 404 KM. It is seen that one municipality generates about $30 \%$ of the average salary over the RS level, while the other achieves almost $50 \%$ lower than that. When it comes to fluctuation of average net salary per type of municipality, it can be seen that it does not deviate much from the average RS salary.

Table 4 Number of employees and average net salaries in RS per municipalities

\begin{tabular}{|c|c|c|c|c|c|}
\hline \multirow{2}{*}{$\begin{array}{l}\text { Type of local } \\
\text { municipalities } \\
\text { according to } \\
\text { development }\end{array}$} & \multicolumn{2}{|c|}{ Employees } & \multirow{2}{*}{$\begin{array}{l}\text { Persons looking } \\
\text { for a job } \\
(2016)\end{array}$} & \multicolumn{2}{|c|}{ Average net salary } \\
\hline & 2015. & 2016. & & 2015. & 2016. \\
\hline Developed & 187.874 & 193.790 & 84.638 & 810,5 & 816,0 \\
\hline Middle-developed & 33.015 & 33.793 & 23.160 & 792,5 & 804,5 \\
\hline Underdeveloped & 16.541 & 16.722 & 16.519 & 710,0 & 716,0 \\
\hline $\begin{array}{l}\text { Heavily } \\
\text { underdeveloped }\end{array}$ & 8.545 & 9.000 & 12.124 & 754,5 & 760,0 \\
\hline Total & 245.975 & 253.305 & 136.441 & 831,0 & 836,0 \\
\hline
\end{tabular}

Source: Author's calculation acording to Prijedlog strategije razvoja lokalne samouprave u RS 2017-2021, 2017.

In the total export realized in 2015, Banja Luka participated with $15.9 \%$, Derventa with $9.4 \%$ and Zvornik with 9.2\%. In total imports Banja Luka participated with 37.7\%, Bijeljina with 10.9\%, Laktaši with $8.3 \%$. The volume of foreign trade exchanges grows year after year, and the coverage of imports by export is also increasing. The largest volume of imports and exports is realized in developed municipalities (70\% of exports and $85 \%$ of RS imports). By contrast, the extremely underdeveloped municipalities have an average of $1-3 \%$ of RS exports, or $0.5-0.9 \%$ of RS imports.

Table 5 Export and import in RS per municipalities in $000 \mathrm{KM}$

\begin{tabular}{|l|r|r|r|r|}
\hline \multirow{2}{*}{$\begin{array}{c}\text { Type of local } \\
\text { municipalities } \\
\text { according to } \\
\text { development }\end{array}$} & \multicolumn{2}{|c|}{ 2015. } & \multicolumn{2}{c|}{ 2016. } \\
\cline { 2 - 5 } \multicolumn{1}{c|}{ Export } & \multicolumn{1}{c|}{ Import } & \multicolumn{1}{c|}{ Export } & \multicolumn{1}{c|}{ Import } \\
\hline Developed & 1.850 .424 & 3.697 .275 & 2.022 .004 & 3.746 .692 \\
\hline Middle-developed & 539.174 & 467.304 & 561.692 & 482.844 \\
\hline Underdeveloped & 173.112 & 139.750 & 190.693 & 131.402 \\
\hline Heavily underdeveloped & 43.275 & 24.622 & 80.843 & 38.437 \\
\hline Unallocated & 3.792 & 2.274 & 1.444 & 1.316 \\
\hline Total & 2.609 .777 & 4.331 .225 & 2.856 .676 & 4.400 .691 \\
\hline
\end{tabular}

Source: Author's calculation acording to Prijedlog strategije razvoja lokalne samouprave u RS 2017-2021, 2017.

There is a low level of investment in the Republika Srpska, both domestic and foreign. The reason for this is certainly a weak investment image of the country, lack of base infrastructure and human resources in underdeveloped areas. Insufficient infrastructure development refers to poor road network, electricity and water supply issues in some areas. Inadequately developed municipalities 
have not developed any service activity - there is a shortage of health facilities, schools, shops, etc.

One of the major shortcomings when it comes to the development of municipalities in RS is certainly the weak institutional capacity. This is primarily related to inefficiency in the work of local government, the lack of quality staff, poor mechanisms for inter-municipal cooperation, lack of planning documents for certain parts of the country.

To solve the problem of uneven development of local government in the RS it is necessary to attract domestic and foreign investment in underdeveloped areas. In order to achieve this, it is necessary to improve the business environment, administrative procedures, retraining and educating the population, create capital intensive production rather than labor intensive production.

\section{CONCLUSION}

Republic of Srpska has very pronounced differences in the development of municipalities located in its territory. Emphasizing the importance of developed and medium-developed municipalities, by local and state authorities, only deepen these differences. Underdeveloped areas are increasingly faced with negative natural growth, low employment, small and declining population, low rates of imports and exports, and so on.

Developed and medium developed municipalities proved to be the most competitive in all observed indicators - have the highest number of inhabitants, the majority of the working population, the largest volume of foreign trade, the highest average salary, the highest rate of natural population growth, ie the lowest negative. As the brightest example among developed municipalities, we can mention the City of Banja Luka.

The basic task of the macroeconomic policy of Republic of Srpska is to promote economic development through appropriate regulation and proper channeling of financial resources with a goal to raising living standards in less developed areas and preventing their demographic discharge. We need a clear policy and plan also, which will lead to a better use of natural resources in underdeveloped areas. 


\section{LITERATURE}

Bander, W. 1959. "Impact of Agricultural Adjustment on Community Structure". Rural Socionogy in a Changing Economy. Urban.

Bartik, T. 2003. "Local Economic Development Policies". Upjohn Institute Working Paper No. 03-91.

Batley, R. and Stoker, G. 1991.Local Government in Europe - Trends and Developments. London: Macmillan.

Begović, B. and Vacić, Z. and Matković, G. 2006. Lokalni ekonomski razvoj. Beograd: Centar za liberalno-demokratske studije.

Bennet, R. 1990. Decentralization, Local Government and Markets. Oxford: Clarendon Press.

Direkcija za ekonomsko planiranje Bosne i Hercegovine. 2017. Ekonomski trendovi: Godišnji izvještaj za 2016. godinu. Sarajevo: DEP.

Đorđević, S. 2012. Renesansa lokalne vlasti: uporedni modeli. Beograd: Čigoja štampa.

Geissel, B. 2009. "How to improve the Quality of Democracy? Expiriences with Participatory Innovations at the Local Level in Germany". Political Science and Political Sociology. Issue 93. Vol. 27. No. 4.

King, A. 1992. Local Government Economics in Theory and Practice. London: Routledge.

Ministarstvo uprave i lokalne samouprave Republike Srpske. 2017. Prijedlog strategije razvoja lokalne samouprave u RS 2017-2021. Banja Luka: Ministarstvo uprave i lokalne samuoprave RS.

Osborne, D. and Gaebler, T. 1992. "Reinventing government". A Willian Patrick Book. Addison Wesley Publishing Company.

Pejanović, M. and Sadiković, E. 2010. Lokalna i regionalna samouprava u Bosni i Hercegovini. Sarajevo/Zagreb: Šahinpašić.

Peters, G. 1998. Comparative Politics: Theory and Methods. Basinstoke: Macmillan.

Pusić, E. 1963. Lokalna zajednica. Zagreb: Narodne novine.

Radulović, M. Dejan. 2013. Regionalna politika i regionalni razvoj - Srbija. Beograd: Narodna biblioteka Srbije.

Reiss, A. J. 1959. Sociological Studies of Communities. Madison: Frontiers of Community Research and action.

Sellers, J. 2002. Governing from Below. UK: Cambridge University Press.

Sullivan, A.M. 1990. The Urban Economics. Boston: Richard D.IRWIN Inc. Homewood.

Šuvar, S. 1973. Između zaseoka i megapolisa. Zagreb: Centar za sociologiju sela, Institut za društvena istraživanja sveučilišta u Zagrebu.

Waltzer, N. 1995. Local economic development. Westview Press. 